\title{
The Present Academic Higher Education in the China's Supply-Side Reform
}

\author{
Weimin Yuan ${ }^{1,2, *}$ Yajuan Wang ${ }^{1}$
}

\author{
${ }^{1}$ Foreign Trade and Business College, Chongqing Normal University, Chongqing, China \\ ${ }^{2}$ Assumption University, Bangkok, Thailand \\ *Corresponding author. Email: 420341229@qq.com
}

\begin{abstract}
With the further development of globalization and coming of the "Internet Plus", China's academic higher education is urgently required to prepare different professional talents as an active response to the challenge from outside. It is also greatly stimulated by nation-wide supply-side reform in Chinese economy. Based on the context above-mentioned, this paper aims to make the exploration of the supply-side reform of China's academic higher education in the following aspects through the literature study and documentary analysis: the problem of the present academic higher education in China, the responding reasons, and the responsive solution to the problem. Consequently, it can be found that only with the dramatically systematic reform in the structure of Chinese higher education, the pool of talents from higher education can be built for the supply-side reform in the nation-wide economy. Thus it can be concluded that the present reform of China's academic higher education is the supply-side reform in nature and a systematic project with the involvement of all factors related, internal and external.
\end{abstract}

\section{Keywords: academic higher education, supply-side reform, systematic project, China}

\section{INTRODUCTION}

Since the implementation of the policy of opening up and reform in China, Chinese higher education has experienced great change in many aspects, such as the number of colleges and universities, students, the types of educating cycle, and the nature of educating institutes, etc. 1999 is its historically important year. Since this year, Chinese higher education starts its times of expansion. On the one hand, the expansion can provide more talents for labor pool of white and blue collars, catering for the urgent need arising from the situation of opening up and reform (Brandenburg \& Zhu, 2007); on the other hand, this is an impediment policy to lessen the increasingly competitive entrance admission examination for colleges and universities in China, bestowing the chance to more average students gaining an access to higher education. More and more colleges and universities follow the step of expansion. More and more new colleges and universities emerge in every corner of China, even leading to the movement of building the cities of colleges and universities. Actually, the expansion is a half-blessing. On top of the advantages brought by the expansion, one fact is very obvious that the quality of higher education is greatly influenced owing to the subjectively negligence and objectively insufficiency in all types of resources. In order to reverse the situation, the corresponding reform movement in Chinese higher education can be found in the 2003-2007 Action Plan for Invigorating Education (MoE, 2004). A tendency is observed which could be described as from quantity to quality (Brandenburg \& Zhu, 2007).

Consequently, according to the Quality Assurance Association (QAA), two state programmes which can be "described as 'pivotal' in modernizing and enhancing the quality of higher education have been introduced: Project 211 and Project 985". The initiative of Project 211 is written in the Ninth Five-Year Plan of China with the very aim to "training high-level professional manpower to implement the national strategy for social and economic development, the project has great significance in improving higher education, accelerating the national economic progress, pushing forward the development of science, technology and culture, enhancing China's overall capacity and international competitiveness, and Laying the foundation of training high-level professional manpower mainly within the educational institutions at home." ("Projects 211 and 985", 2020).

From the description above, it is expected that colleges and universities founded by 211 project can bring standard for quality, that is to say, the example for other colleges and universities in China. A little bit different from 211 project, 985 project puts quality in a 
wider sense, aiming to construct world-renown colleges and universities, as president Jiang Zemin declared that "China must have a number of first-rate universities of international advanced level" (Ibid). It is explicitly stressed in the Action Plan for Invigorating Education Toward the 21st Century (MoE, 1998). Project 985 and Project 211 are two most important strategies of the Chinese government concerning the quality aspect in the overall massification of higher education. Objectively some universities aided by these funds make great progress in themselves, even stepping into the rank of universities with world reputation. However, they do not play a very obvious and important role in enhancing the standard for quality as example of other colleges and universities, on the contrary, they, to some extent, are seen as lions with the biggest share of all educational resources in China. Admittedly, the efforts to improve the quality of higher education by the two project prove to be a great failure without a dint of real meaning to the present situation of the quality of higher education. The fact has to be known that the situation is still as it was before the implementation of the two projects, even worse than it was. One of urgent problems arising from excessive expansion of higher education lies in the unemployment of college or university graduates(Brandenburg \& Zhu, 2007), even leading to a "skyrocking unemployment rate among new college graduates" (Melvin, 2006). This is aftermath of massification initiative of Chinese higher education because it exerts great influence over the quality of colleges or universities and students involved. The connection between the unemployment of college students and the quality of Chinese higher education is a long-time discussed topic in average Chinese citizens. At this time Chinese higher education has lost its past glory and fallen into circle full of doubts and questions. This is largely because whether college students employ or not matter with the welfare of each Chinese family, more importantly, with the hope of each family. The perennial devil of unemployment cannot be effectively stopped its fast step though Chinese government has made great efforts, including the combination of 211 and 985 projects as well as The 2003-2007 Action Plan initiating the implementation of the Qualities-oriented Education Project for the New Century(MoE, 2004). This especially true for the year of 2020. The year witnesses the worst epidemic plague of new coronary virus in the world. It ruins people's health, rakes people's lives, crash the economy, leaving people impossible to work, even no work to be found. For the graduates of 8.74 million from Chinese colleges and universities, the situation is worsening than ever before owing to the plague. In order to cope with this situation, Chinese government expands the number of enrollment of students from short-cycle colleges (or special colleges) to long-cycle colleges or universities. In 2020 alone, the number of expansion amounts to 320,000. Meanwhile, the number of postgraduates is also expanded by 189.000. Together others, the two measures effectively stimulate the employment of this year. However, the final result cannot be too visibly positive because the great pressure of students' employment still need to be further explored from Chinese higher education itself.

\section{THE ACADEMIC HIGHER EDUCATION IN CHINA'S SUPPLY-SIDE REFORM}

\section{A. The reform of Chinese higher education}

The very deep-rooted reason does not lies in the quality issue of Chinese higher education, but in its orientation in a different context. In the age of elite education, higher education is oriented as place to prepare academic talents for national development. Students learn and are taught for the accumulation of knowledge, very limited to the orientation of discipline of their own major. They have no more chance to cross the borders between or among other disciplines, still more chance to integrate different disciplines for the acquisition of professional competence required by the market waiting for them in the future career. Consequently, after the massification came into being in China, more and more college or university graduates, even more and more post-graduates, cannot find their jobs for making a living, much more a job for doing an academic research. It is an obvious fact that this type of orientation is not in line with the reality in market. The gap between higher education and real profession has been increasingly widened with the long-time persistence in academic-oriented education. It is high time that proper efforts have been made to reverse the situation. Fortunately, at the very crucial moment, Chinese government made decision to lead some colleges and universities to get away from the academic orientation into the track of applied-oriented ones with the focus on the acquisition of professional competence for future career (General Office of the State Council, 2014). According to this decision, three key Ministries of Chinese government (Ministry of Education, National Development and Reform Commission, and Financial Ministry) jointly issued the guideline of leading some universities and colleges to transform into applied-oriented ones with the aim to speed up the reform in higher education in the Chinese context. It is the first time for Chinese government to attach great importance to higher education with specific measure to classify Chinese higher education into different orbits, with minority of universities and colleges as academic-oriented, and majority of universities and colleges as applied-oriented. In fact, from the guideline, some problems about Chinese higher education can be found as the followings: the increasingly acute structural contradiction, the aggravating homogenization, the enduring employment difficulty and decreasing rate of employment quality of 
college graduates, the uncomplete establishment of educating mechanism of talents with the orientation on application, versatility, and innovation, and the unadaption of the structure and quality of talents' education to the demand of the adjustment of national economic structure and the upgrading of industries (MoE, 2015). At this crucial moment, colleges and universities involved have to follow the pace of the reform of economy in China, realizing the great importance and urgency of the transformation of universities and colleges and in the spirit of reform and innovation push forward their own transformation . Thus, in April, 2014, in response to government's strategic deployment, 178 colleges and universities meet together in Zhumadian in Henan Province to explore how to make some colleges and universities being transformed and how to construct applied technical colleges and universities with Chinese characteristics. This is very famous prepare "Zhumadian Consensus" ("Zhumadian Consensus," 2014). It is also the proclamation of the action from colleges and universities involved in the reform of higher education in China. It really means the very starting point of Chinese higher education in nature. Since then, the reform of higher education has been accelerated by Chinese government along with the reform of economy.

\section{B. Academic higher education in supply-side reform}

In 2016, in the 13th meeting of the Central Finance and Economics Leading Group, Chinese President Xi Jinping pointed out that

The supply-side structural reform matters with the overall situation and long-term development. It is necessary to deeply understand the background of the times. At present, there are periodic and aggregate problems in China's economic development, but structural problems are the most prominent. The main aspect of contradictions is on the supply side. To accurately grasp the basic requirements, the fundamental purpose of supply-side structural reform is to improve the quality of supply to meet needs, and to make the supply capacity better meet the people's growing material and cultural needs; the main direction is to reduce invalid supply, expand effective supply, and improve the supply structure. The adaptability of the demand structure is currently focused on promoting the five tasks of "three eliminations, one reduction and one supplement"; the essential attributes are to deepen reforms, promote reform of state-owned enterprises, accelerate the transformation of government functions, and deepen basic reforms in the areas of price, finance and taxation, finance, social security (Xinhua, 2016).

From president's speaking, the very purpose of supply-side structural reform lies in the improving the quality of supply to meet needs. As one of fields in the reform, higher education also faces the quality problem arising from the structural problem, especially invalid supply. As was expected, in the end of the 13th meeting of the Central Finance and Economics Leading Group, President XI, emphasized that, "human capital must be strengthened and increased great investment in it so as to improve the quality of education and build a modern vocational education system" (ibid). One fact here is that the reform of higher education is attached great importance to cater for the present demand of economic reform. Whether it is successful or not directly matters with the whole situation of economic reform. That the reform of higher education is raised to the great level suggests that Chinese government has realized the great importance of education in the social and economic development and made series of strong measures to prepare enough talents for labor market. As is suggested by Wu Jing and Liu Yizhan, the reform of higher education has to be linked up with labor market. Under the long-time influence of the planned economy model, the seclusion of Chinese colleges and universities from the outside world has become increasingly apparent. This makes teaching detached from market demand and programme settings and practical applications separated from each other for long. It belongs to structural problem of higher education so that The State Council of People's Republic of China put forward a major deployment of "leading colleges and universities to transition to the applied technological ones". This transition is not only in line with the long-term development strategy of Chinese economic restructuring, but also helps to reverse the current shortage of application-oriented talents in the job market. (Xinhua, 2014). To great extent, it is not only a question of whether graduates employ or not but a question whether higher education can provide a pool of talents for the development of economy and industries in China. As in economy, the reform of supply front is also urgently needed in higher education when it comes into the later stage of postpopularization education with the gross enrollment rate up to $40 \%$. The stag calls for the qualitative change in the talent training specifications of higher education (Liu, 2017). Hanqing Wang also points out that only turning to the reform of supply front of higher education can enhance its quality. He lays emphasis on the lacking of effective supply of higher education again. Constructive advice by him is presented as the followings: Updating the concept of supply and establishing an innovative, pragmatic, and open schooling philosophy, Optimizing the supply structure and providing a rich, diverse and diverse education supply, optimizing the supply structure for diversified programme options, optimizing the supply structure for a variety of courses, optimizing the supply structure for the diversification of teaching formats, Promoting supply upgrades and achieving scientific, accurate and high-quality talent supply, and enhancing the supply 
capacity of innovation and entrepreneurship education(Wan, 2016). All advice above-mentioned points out the long-time structural problem of present higher education in China. In 2018, the number of colleges and universities has reached 2663 . The number of new enrollment amounts to 7.9099 million in this year. The number of total students in colleges and universities is up to 28.3103 million. The data shows that "We have built the world's largest higher education system. The gross enrollment rate of higher education has reached $48.1 \%$. China is about to enter the popularization stage from the popularization stage of higher education", Fan Hailin, deputy director of the Department of Higher Education of the Ministry of Education, said at the press conference (Wu, 2019). The extent of popularization will be undoubtedly accelerated by new move from government in order to lessen the pressure of employment incurred by the outbreak of the novel coronavirus disease (COVID-19) in 2020. The news from China Network on February 26th said that the State Council executive meeting was held in Beijing on the 25th. The meeting proposed that the scale of graduate enrollment and the scale of students into Top-up program (from Junior colleges to universities) in this year will be expanded (Guo, 2020). The further effort was made by Chinese State Council with the guideline released on Mar20th, "to expedite the recovery of employment and keep it stable to counter the impact from the novel coronavirus disease (COVID-19) outbreak. In terms of employment for college graduates, the guideline said that the scale of recruitment for state-owned enterprises, public institutions and the military will be expanded along with graduate school enrollment and professional internship posts" (Xinhua, 2020). At a regular briefing on the policies of the State Council Office held on March 25, more emphasis is laid that the implementation of phased and targeted tax and fee reduction policies be expedited to expand employment channels for college graduates (CCTV, 2020). From the analysis above, one fact can be found that the employment of colleges and universities has been paid great attention by Chinese government. It has been the top priority of national affairs, not simply the personal things of graduate's own. It matters with the success of the reform of nationwide supply front. Only if its own structural problem is been effectively dealt with, the quality of higher education in China can be greatly enhanced. At that time, the pressure of employment of graduates can be drastically lessened and talents ready for labor market can be easily found. This is why Chinese State Council has proposed the policy of transformation of colleges and universities. In fact, very early in the process of designing the overall policy of modern vocational education, the construction of application-oriented colleges and universities has become an important task in the construction of the entire modern vocational education system. It is also an important task in the reform of higher education. In the "Thirteenth Five-Year Plan" of the Fifth Plenary Session of the Eighteenth Central Committee of the Chinese Communist Party, the overall reform and development of education has been fully deployed. The transformation and development has become the strategic focus of higher education reform during the "Thirteenth Five-Year Plan"(Chen, 2015). It means that the transformation of higher education does not arise from the impedance but from the long-time strategic arrangement for the reform and development of national economy, culture, and people's wellbeing. For all colleges and universities, no matter whether they are involved or not, they all have to realize situation, and fulfil their obligation to make great concerted efforts to explore the specific way to push forward the giant project of transformation.

\section{CONCLUSION}

From the exploration above, several facts can be found. One is that Chinese higher education enters the era of massification or popularization(Chaokai, 2019); another is that higher education in such an era has to be reformed with majority of colleges and universities transformed into application-oriented ones because of the problems in reality and the very problem in higher education itself; last one is that the problem of higher education is largely attributed to its irrational structure, especially its orientation. This problem belongs supplyside one as that has been found in national economy in our whole country. The supply-side reform needs to be implemented and sped up in every aspect in the present China, including in Chinese higher education. The reform is a systematic project, requiring all parties involved to make concerted efforts within and outside themselves. Outside higher education, on the one side, it needs to artistically and creatively deal with the relations between higher education or academic higher education and vocational higher education, especially with specific focus on the proportion of their number and the extent of mutual integration. Within higher education, it involves its scale or size, the levels, orientation, etc. They all involves supply-side problem. In nature, it is the structural problem. This has to be done systematically, especially put in the system of whole national economy, politics, and culture, etc. The structural supply-side reform still needs more scholars to explore the way to facilitate the transformation of majority of local colleges and universities in China as an active response to this problem in Chinese higher education.

\section{References}

[1] Brandenburg, U., \& Zhu, J. (2007). Higher Education in China in the light of massification and demographic change Lessons to be learned for Germany. Arbeitspapier Nr. 97 Oktober, (10), 64 
Retrieved

http://citeseerx.ist.psu.edu/showciting?cid=14049543

[2] CCTV. (2020). Ministry of Human Resources and Social Security: Accelerate the implementation of phased tax and fee reduction policies to stabilize employment. Retrieved October 31, 2020, from http://news.cnr.cn/native/gd/20200326/t20200326_525030292.s html

[3] Chaokai, G. (2019). Ministry of Education: The gross enrollment rate of higher education reaches $48.1 \%$ and will enter the stage of popularization of higher education. Retrieved from China News Network website: http://www.chinanews.com/sh/2019/02-26/8765168.shtml

[4] Chen, F. (2015). Speed up the exploration of the transformation and development path of local universities To see the general trend of future development. Retrieved October 31, 2020, from China Education Newspaper website: http://www.cssn.cn/gx/gx_gxms/201511/t20151130_2718831.s html

[5] General Office of the State Council. (2014). Li Keqiang presided over an executive meeting of the State Council to deploy and accelerate the development of modern vocational education. Review and pass the "Personnel Management Regulations (Draft) for Public Institutions." Retrieved from http://www.gov.cn/ldhd/2014-02/26/content_2622673.htm

[6] Guo, Z. (2020). Issued by China | State Council: Expanding the scale of enrollment and undergraduate upgrading. Retrieved October 31, 2020, from China Network website: http://news.china.com.cn/txt/2020-02/26/content_75747063.htm

[7] Liu, G. (2017). The fifth reflection on China 's higher education process in 2016: With a gross enrollment rate of $40 \%$, the postpopularization stage of higher education requires "qualitative changes". Retrieved March 20, 2020, from http://blog.sciencenet.cn/home.php?do=blog\&id=1026201\&mo $\mathrm{d}=$ space\&quickforward $=1$ \&uid $=359436$

[8] Melvin, S. (2006). China's College Revolution. The Wilson Quaterly, 30(4).

[9] MoE. (1998). Action Plan for invigorating Education towards the 21st Century. Retrieved October 29, 2020, from http://old.moe.gov.cn/publicfiles/business/htmlfiles/moe/s6986/ 200407/2487.html

[10] MoE. (2004). 2003-2007 Action Plan for Invigorating Education. Retrieved October 29, 2020, from Xinhaua News Agency website: http://news.eastday.com/eastday/news/news/node4947/node160 18/userobject1ai154064.html

[11] MoE. (2015). The three departments issued guidance on guiding the transformation of some local ordinary undergraduate colleges and universities to Guiding Opinions of the Ministry of Education , National Development and Reform Commission , and the Ministry of Finance.Projects 211 and 985. (2020). https://doi.org/10.4135/9781529714395.n455

[12] Wan, H. (2016). Enriching the supply structure and improving the quality of higher education. Retrieved October 20, 2020, from China Education Newspaper website: http://cssn.cn/ddzg/ldhc/201612/t20161219_3351710.shtml

[13] Wu, Y. (2019). Ministry of Education: The gross enrollment rate of higher education reaches $48.1 \%$ and will soon enter the stage of popularization. Retrieved March 27, 2020, from China.com.cn https://www.sohu.com/a/297725835_116897

[14] Xinhua, A. (2014). Commentary: Higher Education Reform Must Link Job Market. Retrieved from http://www.gov.cn/xinwen/2014-05/13/content_2679012.htm

[15] Xinhua, A. (2016). Xi Jinping hosted the 13th meeting of the Central Finance and Economics Leading Group. Retrieved $\begin{array}{lrrr}\text { March } & 20, & 2020, & \text { from } \\ \text { http://cpc.people.com.cn/n1/2016/0516/c64094-28354852.html }\end{array}$

[16] Xinhua, A. (2020). THE PEOPLE ' S REPUBLIC OF CHINA China rolls out measures to further ensure employment against COVID-19 impact. Retrieved March 26, 2020, from http://english.www.gov.cn/policies/latestreleases/202003/20/con tent_WS5e74af1fc6d0c201c2cbf0ec.html

[17] Zhumadian Consensus. (2014). Retrieved March 20, 2020, from Applied Technical University or College Alliance website: http://www.csdp.edu.cn/article/812.html 